Article

\title{
Best Crop Rotation Selection with GIS-AHP Technique Using Soil Nutrient Variability
}

\author{
Chiranjit Singha ${ }^{\circledR}$, Kishore Chandra Swain * and Sanjay Kumar Swain \\ Department of Agricultural Engineering, Institute of Agriculture, Visva-Bharati, Sriniketan, Birbhum, \\ West Bengal 731236, India; singha.chiranjit@gmail.com (C.S.); sksifs2009@gmail.com (S.K.S.) \\ * Correspondence: kishore.swain@visva-bharati.ac.in
}

Received: 18 April 2020; Accepted: 25 May 2020; Published: 9 June 2020

check for updates

\begin{abstract}
Crop selections and rotations are very important in optimising land and labour productivities, enhancing higher cropping intensities, producing better crop yield. A land suitability analysis system based on the analytical hierarchy process (AHP) technique coupled with the Geographic Information System (GIS) software environment can be a unique tool for better crop selection. The AHP-GIS technique was used in land suitability analysis in crop rotation decisions, for rice-jute (Kharif season) and potato-lentil (Rabi season) crops in the Hooghly District, West Bengal, India. The study area covering 291 ha was classified based on eight major soil nutrient levels with 70 randomly selected plots for soil sampling and analysis. The soil nutrient variability was examined with descriptive statistics followed by best semivariogram-based model selection for kriging interpolation in the ' $\mathrm{R}$ ' software environment. The pairwise comparison matrix based ranking of parameters and giving weights was carried out considering the importance of each parameter for specific crops. The total area, being under the major rice-potato belt, could be classified from the suitability view point to the 'highly suitable' $\left(\mathrm{S}_{1}\right)$ class occupying $29.2 \%$, and 'not suitable' $(\mathrm{N})$ class; $4.5 \%$ for rice, about $6.5 \%$ of land is 'highly suitable' $\left(\mathrm{S}_{1}\right)$, 'and nearly $2.1 \%$ area is 'not suitable' (N) for jute; and $21.3 \%$ is 'highly suitable' $\left(\mathrm{S}_{1}\right)$ for potato and $12.4 \%$ for lentil crops. The yield maps showed nearly $75 \%$ and $90 \%$ of the area for rice and potato crops, respectively, gave sound crop yield. Furthermore, the GIS platform was used for crop rotation analysis to spread multiple seasons ensuring better crop management in long run. Overall, 25\% of the rice crop area for jute in Kharif and $8 \%$ of potato crop area for lentil in the Rabi season were recommended as replacements.
\end{abstract}

Keywords: land suitability; rice and potato; semivariogram; kriging interpolation; pairwise comparison

\section{Introduction}

Achieving agricultural sustainability has been given the highest priority in both developed and developing nations. It can be attained through studying cropping system analysis (CSA), which is defined as the cropping pattern and its management to derive maximum benefits from the given resources under specific environmental conditions. West Bengal produced 16.2 million tons of rice, which is highest among the Indian states [1]. However, the growth rate of rice production in the state was $6.39 \%$ during 1980-1981 to 1990-1991, slowing down to 1.47\% during 1991-1992 to 2000-2001, and more recently the growth rate turned negative at $-0.25 \%$ [2]. In the other hand, the potato production was enhanced by 22\% in 2016-2017 which causes low market price [3]. Additionally, the profit margin was continuously reduced with a high cost of "Jalandhar" based seed producing low export-quality potatoes [4]. Overall, the farmers are stressed with low profit margins from their farmland. So, there is an immediate need for a land suitability study to decide the best crop rotation for farmland in the region. 
A cropping pattern is a spatial phenomenon $[5,6]$ and refers to the sequence and arrangements of crops in an area at a particular space and time [7,8]. Crop rotation, growing one crop after another on the same piece of land at different timings (seasons) without impairing the soil fertility, should be practised. In crop rotation, the succeeding crops are of a different genus, species, subspecies or variety than previous crop for optimum utilization of resources.

Timely information about the present cropping pattern and its effects are pre-requisites to devise an ideal cropping pattern within an agroecological region. The Food and Agriculture Organization (FAO) [5] proposed land evaluation in terms of two broad classes, 'suitable' (S) and 'not suitable' (N). These two classes can further segregate into four suitability groups, such as: highly suitable, moderate suitable, marginal suitable and not suitable.

The Geographic Information System (GIS) is used as a decision support tool for the land suitability analysis for various developmental activities [9,10]. Land-use suitability mapping and analysis have been carried out with GIS for spatial planning and management [11-13]. Land-use suitability analysis is a multi-criteria evaluation, which aims at identifying the most appropriate spatial pattern for future land use [14], according to specific requirements, preferences, or predictors of some activity [15-18]. GIS is sometimes handicapped in ranking the parameters for suitability analysis.

The analytical hierarchy process (AHP) technique proposed by Saaty [19] is very suitable for ranking the individual parameter in terms of their importance and validated the rankings. AHP can be integrated with GIS applications and used for agricultural land suitability analysis [20-22]. It is one of the promising methods used for the agricultural land suitability analysis based on individual criteria through quantitative analysis [23,24]. In AHP, pairwise comparison matrix is used to rank and estimate the overall weight of individual criteria or parameter. Integration of AHP and GIS helps in developing a better decision support system by creating suitability maps [25-27] for agricultural crops. GIS-assisted land suitability analysis along with AHP was carried out for wheat and barley crop in Ethiopia [28]. The final output map showed that $83.21 \%$ (1945.17 ha) was moderately suitable and $16.79 \%$ (392.52 ha) marginally suitable for wheat crops, and, $86.14 \%$ (2013.61 ha) moderately suitable and $13.86 \%$ (324.08 ha) marginally suitable for barley crops. Similar suitability studies have been carried out using the AHP-GIS technique for, rice crop in Bangladesh [29], various vegetable crops in Java, Indonesia [30], Sorghum crop in Ethiopia [31], and for cotton in Maharashtra, India [32], etc.

In this study, we explored the major crop rotations/systems for Kharif (summer) and Rabi (winter) seasons by carrying out agricultural land-use suitability assessment for rice-jute and potato-lentil crops using AHP-GIS techniques in West Bengal, India. The soil samples data were tested for statistical validity and yields maps were also compared with respective suitability distribution maps before recommending the best crop rotation.

\section{Methodology}

\subsection{Study Area}

This study was carried out in Tarakeswar block, Hooghly district located around 70 kilometres from Kolkata, the state capital of West Bengal, India. The geographical location of the district is within $22^{\circ} 39^{\prime} 32^{\prime \prime}$ to $23^{\circ} 01^{\prime} 20^{\prime \prime} \mathrm{N}$ latitude and $87^{\circ} 39^{\prime} 32^{\prime \prime}$ to $88^{\circ} 30^{\prime} 15^{\prime \prime}$ E longitude. The total area of Hooghly district is around $3149 \mathrm{~km}^{2}$ (Figure 1). The underlying parent material within the study area consists primarily of quaternary alluvial deposits. Alluvial soils, formed by the Damodar-Hooghly river as accumulated sediments, are deposited in the region. The study area lies at an elevation of approximately 0 to $40 \mathrm{~m}$ (MSL). However, the area is formed by flat plains with remarkable topographical homogeneity. The climate in the region is transitional between the $\mathrm{CWg}_{3}$ (warm temperate rainy climate monsoon type with dry winters) and $\mathrm{AW}_{1}$ (tropical Savannah types) types, and the average minimum and maximum temperature is around $15-20^{\circ} \mathrm{C}$ and $28-35^{\circ} \mathrm{C}$, respectively. The average annual rainfall of the district varies from $1200 \mathrm{~mm}$ to $1700 \mathrm{~mm}$ with the major soil type of naranyanapara silty clay loam-cultivated. The area represents an "ustic" soil moisture and "hyperthermic" soil temperature 
regime. Predominance of fertile soils, land and adequate water resources are the key factors facilitating intensive agriculture in the study area [33].

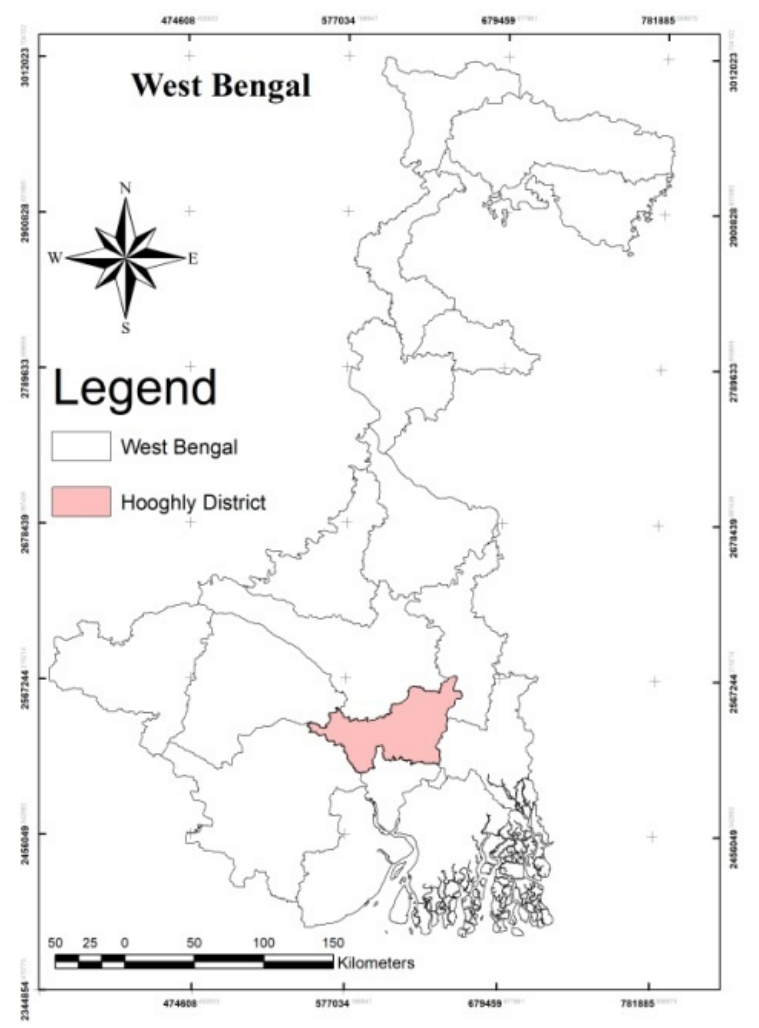

Figure 1. Study area location in West Bengal, India.

The important Kharif crops are rice, jute, sesame etc. and Rabi crops are potato, mustard, pulse (lentil) and different types of vegetables. Boro paddy (transplanted rice) is also widely cultivated in irrigated areas. The Kana Nadi (Kana River) drainage stream of Hooghly River and deep tube wells etc. supply the required water for irrigation in the study area. Five revenue villages, Aligori, Bajitpur, Basudebpur, Jothsombhu and Kolaikundu of Tarkeswar block, Hooghly district, West Bengal, India, were selected for study. The open series map sheet no. F45K1 (79B/1) developed by Survey of India, 2011 was used for creating base map. The scale of the map was 1:50,000 in the Universal Transverse Mercator (UTM) projection system with World Geodetic System -1984 (WGS-84) datum. The study area is situated in Zone 45 of UTM system between 2528500 to 2530600 Northing and 604500 to 606500 Easting. The base map was created by digitizing the aforementioned topographical map in Arc GIS 10.1 (ESRI, Redlands, CA, USA) software environment. Around nine ground control points (GCPs) were collected using eTrex 20 Global Positioning System (GPS) Receiver (Garmin Ltd., Olathe, KS, USA) for registration of the base map. The features such as, study area boundary, road network including railway track, canal network and ponds etc. have been mapped (Figure 2). The railway track present in the study area connects Howrah and Tarakeswar city. The total study area is around 291 hectares. 


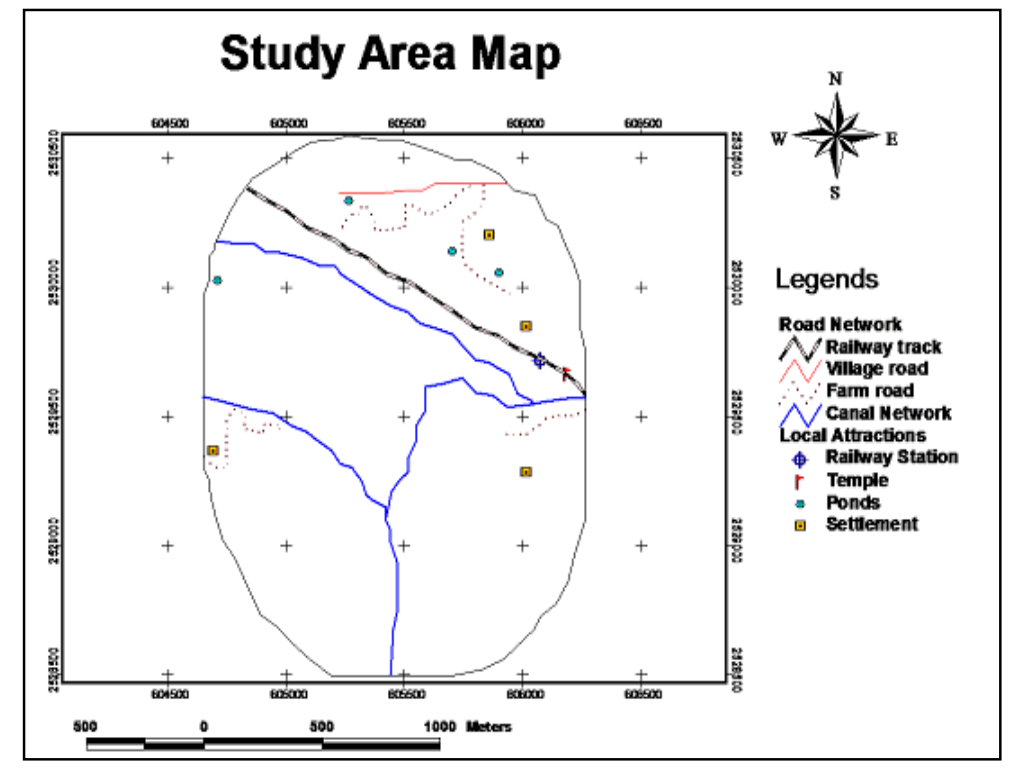

Figure 2. Study area map.

\subsection{Soil Sampling and Analysis}

Soil samples were collected from the study area along with the GPS coordinate point of the Rabi season. Randomly identified 70 plots were selected for soil sample, and crop yield information collection located in the five villages. The soil samples, with a depth of 20 centimetres, were collected at the end of the Rabi season of India during May 2015 [34]. The soil samples were dried, cursed and passed through a 2 millimetres sieved screen. Soil chemical characteristics, such as soil texture, $\mathrm{pH}$, organic carbon, available phosphorus, total nitrogen and total potassium etc., were used along with other parameters to carry out the land suitability study for rice and wheat crop in West Bengal [35]. The availability of zinc and level of electric conductivity were found to be important for rice-wheat crop rotation $[36,37]$.The samples under went laboratory analysis for selected parameters, such as: $\mathrm{pH}$, soil texture, EC, organic Carbon, available N, P, K and Zn, following standard laboratory soil analysis procedures $[38,39]$. Soil texture of soil samples was determined by estimating percentage of sand, silt and clay according to the United States Department of Agriculture (USDA) system using Hydrometer technique [40] followed by textural triangle diagram. The readings of the nutrients were expressed in parts per million (PPM) scale.

\subsection{Statistical Analysis}

Statistical analysis shows the trend and discrepancy in the collected soil nutrient data. Descriptive statistics are important and useful to visualize what the data are showing especially if there is a lot of it. It enables us to present the data in a more meaningful way, which allows simpler interpretation of the data [41]. The descriptive statistics for this study, including minimum, maximum, means, coefficient of variation of physico-chemical properties of soil samples, were evaluated in ' $R$ ' software (Opensource software developed in University of Auckland, New Zealand) environment.

\subsection{Semivariograms Analysis}

The semivariogram is a statistic that assesses the average decrease in similarity between two random variables as the distance between the variables increases, leading to some applications in exploratory data analysis [42]. For stochastic studies, the semivariogram is preferred over co-variance as it does not require knowledge of the mean of the random functions for its estimation [43]. In semivariograms analysis, the choice of the number of basic models appears to be secondary, although it greatly influences the resulting interpretation of the co-regionalization variogram analysis in the 
' $R$ ' software environment. When using linear co-regionalization analysis in a descriptive way, results are acceptable only if they are consistent with any prior physical knowledge or with a new physical interpretation without references to the statistical models that are used [44]. In semivariogram, range is the distance beyond which spatial dependence between soil samples ceases to exist and it can be used as indicator of the appropriate cell size for a field survey in site-specific management [45]. Thus it can be an effective criterion for the evaluation of sampling design and the mapping of soil properties. The value of the nugget varied widely for soil properties. Lower values of the nugget effect $\left(\mathrm{C}_{0}\right)$ indicate low errors in measurements. In general, a nugget/sill ratio $<25 \%$ indicates strong spatial dependency and $>75 \%$ indicates weak spatial dependency; otherwise, the spatial dependency is moderate [46]. The log-transformed selected soil parameters content residuals are correlated, since the corresponding cross-variograms have fairly large sills, particularly when residuals from the same horizons are considered. These restrictions mean that the selected models do not fit the sample variograms very accurately for all cases, although the overall fits are satisfactory for the analysis.

\subsection{Interpolation Analyses for Suitability}

In the present study, ordinary kriging (OK) interpolation method was applied for predicting the spatial distribution of soil nutrient suitability for the crops. Bayesian kriging allows uncertainty in the model parameters to be reflected in the widths of the prediction intervals, thus providing a more reliable prediction of the parameter of interest [47]; kriging uses a semivariogram technique to determine the spatial correlation between two points in that weightings change according to the spatial arrangement of the samples. The root mean squared error (RMSE) values can be estimated using the following Equation (1):

$$
R M S E=\sqrt{\frac{\sum_{i=1}^{n}\left[\hat{z}\left(s_{i}\right)-z\left(s_{i}\right)\right]^{2}}{n}}
$$

where:

$\hat{z}\left(s_{i}\right)$-the predicted value,

$z\left(s_{i}\right)$-the observed (known) value,

$n$-the number of values in the dataset [48].

\subsection{Weightage Analysis in Analytical Hierarchy Process (AHP)}

The suitability level of individual parameters for the crops were mapped in the Arc GIS software environment using suitability range of the parameter for the specific crop (i.e. rice, jute, potato and lentil; Table 1). Being a biological entity, the opinions of 10experts, in the field of agronomy and soil science related to agriculture in general, were sorted for ranking the relative importance of crop nutrients for a particular crop. In this investigation, the evaluation criteria were selected considering the crop requirements in the local conditions. In this MCA (multi-criteria analysis), the factors were selected based on inputs from local experts and reviews of existing literature $[49,50]$. Such an approach produced valuable information on the relative importance of the factors under evaluation and could be a useful precedent for future studies of crop suitability. Specific efforts were made to gain agreement among the experts on final ranking of the parameters. Utilizing the ranking parameters and AHP guidelines, the pairwise comparison matrices for four crops, two in each season (Kharif and Rabi seasons) were estimated. Using this process to standardize the criterion maps, first a pairwise comparison matrix for each parameters and suitability classes (i.e. $\mathrm{S}_{1}$-Highly suitable, $\mathrm{S}_{2}$-Moderate suitable, $\mathrm{S}_{3}$-Marginal suitable, and N-Not suitable) were prepared. The eigenvector weightage of each parameter was calculated using the technique [51]. Random inconsistency index (RI) was also taken [19] for eight parameters (Table 2). The principal eigenvalue $\left(\lambda_{\max }\right)$ and consistency index $\left(\mathrm{CI}=\lambda_{\max } / n-1\right)$ were estimated then the consistency ratio $(\mathrm{CR}=\mathrm{CI} / \mathrm{RI})$ was calculated, to validate the weightage [52] and can be used further for land suitability estimation. 
Table 1. Suitability range for individual soil parameters for the crops.

\begin{tabular}{|c|c|c|c|c|c|c|}
\hline $\begin{array}{c}\text { Soil } \\
\text { Parameters }\end{array}$ & Unit & $\begin{array}{l}\text { Crop } \\
\text { Type }\end{array}$ & $\begin{array}{c}\text { Highly } \\
\text { Suitable }\left(S_{1}\right)\end{array}$ & $\begin{array}{c}\text { Moderate } \\
\text { Suitable }\left(\mathrm{S}_{2}\right)\end{array}$ & $\begin{array}{c}\text { Marginal } \\
\text { Suitable }\left(S_{3}\right)\end{array}$ & $\begin{array}{c}\text { Not Suitable } \\
\text { (N) }\end{array}$ \\
\hline \multirow{4}{*}{ Soil pH } & \multirow{4}{*}{ Reaction } & rice & $6-7.5$ & $7.5-8 ; 4.5-6$ & $8-8.5 ; 4-4.5$ & $>8.5 ;<4.0$ \\
\hline & & jute & $6.5-7.5$ & $5.0-6.5$ & $4.5-5.0$ & $<4.5$ \\
\hline & & potato & 6-7 & $5.0-6.0 ; 7.0-7.5$ & $4.5-5 ; 7.5-8.0$ & $<4.5 ;>8.0$ \\
\hline & & lentil & $6.0-7.5$ & $7.5-8.0 ; 5.5-6$ & $8-8.5 ; 4.5-5.5$ & $>8.5 ;<4.5$ \\
\hline \multirow{4}{*}{$\begin{array}{l}\text { Available } \\
\text { nitrogen } \\
(\mathrm{N})\end{array}$} & \multirow{4}{*}{ ppm } & rice & $>30$ & $20-30$ & $10-20$ & $<10$ \\
\hline & & jute & $>45$ & $30-45$ & $15-30$ & $<15$ \\
\hline & & potato & $>55$ & $35-55$ & $20-35$ & $<20$ \\
\hline & & lentil & $>7.5$ & $5.0-7.5$ & $2.5-5.0$ & $<2.5$ \\
\hline \multirow{4}{*}{$\begin{array}{c}\text { Available } \\
\text { phosphorous } \\
\text { (P) }\end{array}$} & \multirow{4}{*}{ ppm } & rice & $>50$ & $25-50$ & $10-25$ & $<10$ \\
\hline & & jute & $>8$ & $5-8$ & $2-5$ & $<2$ \\
\hline & & potato & $>11$ & $8-11$ & $5-8$ & $<5$ \\
\hline & & lentil & $>11$ & 8-11 & $5-8$ & $<5$ \\
\hline \multirow{4}{*}{$\begin{array}{l}\text { Available } \\
\text { potassium } \\
\text { (K) }\end{array}$} & \multirow{4}{*}{ ppm } & rice & $>60$ & $45-60$ & $30-45$ & $<30$ \\
\hline & & jute & $>30$ & $20-30$ & $10-20$ & $<10$ \\
\hline & & potato & $>55$ & $35-55$ & $15-35$ & $<15$ \\
\hline & & lentil & $>5$ & $10-15$ & $5-10$ & $<5$ \\
\hline \multirow{4}{*}{$\begin{array}{c}\text { Organic } \\
\text { carbon }(\mathrm{OC})\end{array}$} & \multirow{4}{*}{$\%$} & rice & $>1.0$ & $0.66-1.0$ & $0.33-0.66$ & $<0.33$ \\
\hline & & jute & $>1.0$ & $0.66-1.0$ & $0.33-0.66$ & $<0.33$ \\
\hline & & potato & $>0.7$ & $0.5-0.7$ & $0.3-0.5$ & $<0.3$ \\
\hline & & lentil & $>1.5$ & $1.0-1.5$ & $0.5-1.0$ & $<0.5$ \\
\hline \multirow{4}{*}{$\begin{array}{c}\text { Electrical } \\
\text { conductivity } \\
\text { (EC) }\end{array}$} & \multirow{4}{*}{$(\mathrm{dS} / \mathrm{m})$} & rice & $0.0-3.0$ & $3.0-4.0$ & $4.0-5.0$ & $>5.0$ \\
\hline & & jute & $<1.0$ & $1.0-2.0$ & $2.0-5.0$ & $>5.0$ \\
\hline & & potato & $<4$ & 4-6 & 6-8 & $>8$ \\
\hline & & lentil & $0-1.0$ & $1.0-1.5$ & $1.5-2.0$ & $>2.0$ \\
\hline \multirow{4}{*}{$\begin{array}{l}\text { Available } \\
\text { zinc }(\mathrm{Zn})\end{array}$} & \multirow{4}{*}{ ppm } & rice & $>1.5$ & $1.0-1.5$ & $0.5-1.0$ & $<0.5$ \\
\hline & & jute & $>3$ & 2-3 & 1-2 & $<1$ \\
\hline & & potato & $>1.2$ & $0.8-1.2$ & $0.4-0.8$ & $<0.4$ \\
\hline & & lentil & $>1.0$ & $0.8-1.0$ & $0.5-0.8$ & $<0.5$ \\
\hline \multirow{4}{*}{$\begin{array}{l}\text { Soil texture } \\
\qquad(\mathrm{ST})\end{array}$} & \multirow{4}{*}{ Class } & rice & $\begin{array}{l}\text { Clay, silty clay, } \\
\text { silty clay loam }\end{array}$ & $\begin{array}{l}\text { Sandy clay, } \\
\text { loam, silt loam, } \\
\text { clay loam }\end{array}$ & $\begin{array}{l}\text { Sandy clay } \\
\text { loam, sandy } \\
\text { loams, silt }\end{array}$ & $\begin{array}{l}\text { Loamy sands, } \\
\text { sands }\end{array}$ \\
\hline & & jute & $\begin{array}{l}\text { Loam, silty } \\
\text { loam, sandy } \\
\text { clay loam }\end{array}$ & $\begin{array}{l}\text { Silty clay, silty } \\
\text { clay loam, clay }\end{array}$ & $\begin{array}{l}\text { Sandy loam, } \\
\text { clay }>60 \%\end{array}$ & Sand \\
\hline & & potato & $\begin{array}{c}\text { Sandy loams, } \\
\text { sandy clay } \\
\text { loam }\end{array}$ & $\begin{array}{l}\text { Sandy Clay, } \\
\text { silt clay loam, } \\
\text { silt loam, clay } \\
\text { loam }\end{array}$ & Clay, silt & $\begin{array}{l}\text { Fine sand, } \\
\text { loamy sand }\end{array}$ \\
\hline & & lentil & $\begin{array}{l}\text { Loam, silty } \\
\text { loam, sandy } \\
\text { clay loam }\end{array}$ & $\begin{array}{l}\text { Silty clay, silty } \\
\text { clay loam, clay }\end{array}$ & $\begin{array}{l}\text { Sandy loam, } \\
\text { clay }>60 \%\end{array}$ & Sand \\
\hline
\end{tabular}

Table 2. Values of random inconsistency index (RI) for $n=15$.

\begin{tabular}{cccccccccccccccc}
\hline $\mathrm{N}$ & 1 & 2 & 3 & 4 & 5 & 6 & 7 & 8 & 9 & 10 & 11 & 12 & 13 & 14 & 15 \\
\hline R.I. & 0.00 & 0.00 & 0.58 & 0.90 & 1.12 & 1.24 & 1.32 & 1.41 & 1.45 & 1.49 & 1.51 & 1.54 & 1.56 & 1.56 & 1.59 \\
\hline \multicolumn{1}{c}{ Source: [52]. }
\end{tabular}




\subsection{Yield Mapping}

Yield mapping was carried out to have a sound observation on distribution of crop yield in the study area. Maps were developed for both rice and potato crops grown in the Kharif and Rabi seasons, respectively. The areas giving low yield can be allot for alternative crops such as jute and lentil crops. The maps had four yield classes in line with four classes of suitability distribution maps.

\section{Results and Discussion}

\subsection{Soil Sample Analysis}

The study area is located on the deltaic plain formed as alluvial deposits carried by the Damodar river in Hooghly. Alluvial land and its soils often show spatial variations in their properties over short distances. The seventy samples were analyzed for eight parameters and verified statistically. The $\mathrm{pH}$ values of the soil samples ranged between 4.11 and 6.33 and electrical conductivity ranged from $0.10 \mathrm{dS} \mathrm{m}^{-1}$ to $1.73 \mathrm{dS} \mathrm{m}^{-1}$. The soil texture class widely varied from sandy loam to clay, with clay content ranging $22 \%$ and $63 \%$ and sand content between $11 \%$ and $65 \%$. The mean values for organic carbon was around $0.5 \%$. As for macronutrients, available $\mathrm{P}, \mathrm{K}$ and $\mathrm{Zn}$ levels showed high level variation among the plots. Available $\mathrm{N}$ varied between $10 \mathrm{ppm}$ and $55 \mathrm{ppm}$ with average value of $28 \mathrm{ppm}$. Mulla and McBratney [59] reported that when the coefficient of variation (CV) is lower than $15 \%$, variability is classified as low; while $15 \%$ to $35 \%$, classified as moderate; and above $35 \%$, classified as high. In the current study, $\mathrm{pH}$ content had low CV; OC, N, Zn, sand, silt, and clay had moderate CVs, whereas the EC and P content had a high level of CVs (Table 3). The N, P and K have numerical high maximum values in terms of ppm.

Table 3. Descriptive statistical analysis of physical and chemical properties of soil samples $(n=70)$.

\begin{tabular}{ccccccccccccc}
\hline & $\mathbf{p H}$ & $\mathbf{l o g}$ & $\begin{array}{c}\text { EC } \\
\mathbf{p H}\end{array}$ & $\begin{array}{c}\text { Log EC } \\
(\mathbf{d s} / \mathbf{m})\end{array}$ & $\begin{array}{c}\text { OC } \\
(\mathbf{d s} / \mathbf{m})\end{array}$ & $\begin{array}{c}\mathbf{N} \\
\mathbf{( \% )}\end{array}$ & $\begin{array}{c}\mathbf{P} \\
(\mathbf{p p m})\end{array}$ & $\begin{array}{c}\text { K } \\
(\mathbf{p p m})\end{array}$ & $\begin{array}{c}\text { Zn } \\
(\mathbf{p p m})\end{array}$ & $\begin{array}{c}\text { Sand } \\
(\mathbf{p p m})\end{array}$ & $\begin{array}{c}\text { Silt } \\
(\mathbf{\%})\end{array}$ & $\begin{array}{c}\text { Clay } \\
(\mathbf{\%})\end{array}$ \\
\hline Mean & 4.87 & 1.57 & 0.56 & -0.70 & 0.54 & 27.9 & 197.1 & 76.93 & 2.23 & 42.64 & 18.2 & 39.2 \\
SD & 0.57 & 0.11 & 0.31 & 0.53 & 0.18 & 8.72 & 60.8 & 29.64 & 0.62 & 13.75 & 5.57 & 9.48 \\
Skewness & 1.14 & 0.92 & 1.66 & -0.40 & 0.01 & 0.96 & -1.64 & 0.58 & 0.42 & -0.59 & 0.27 & 0.77 \\
Kurtosis & 0.40 & 2.94 & 3.92 & 4.07 & 0.36 & 2.23 & 1.07 & -0.06 & -0.25 & -0.42 & -1.7 & 0.30 \\
Minimum & 4.11 & 1.41 & 0.10 & -2.30 & 0.13 & 10.04 & 35.07 & 25.90 & 1.16 & 11.7 & 10.0 & 22.3 \\
Maximum & 6.33 & 1.84 & 1.73 & 0.54 & 0.95 & 55.2 & 231.6 & 150.73 & 3.88 & 66.4 & 28.7 & 63.6 \\
CV (\%) & 11.69 & & 54.37 & & 33.1 & 31.3 & 30.84 & 38.5 & 28.0 & 32.2 & 30.7 & 24.2 \\
\hline
\end{tabular}

Note: EC-electrical conductivity; OC-organic carbon; $\mathrm{N}$-available nitrogen; $\mathrm{P}$-available phosphorous; $\mathrm{K}$-available potassium; $\mathrm{Zn}$-zinc level; $n-$ no. in samples; SD—standard deviation CV (coefficient of variation): $<15=$ low variation, $15-35=$ moderate variation, $>35=$ high variation; Skewness: $<|-+0.5|=$ normal distribution, $0.5-1.0=$ application of character changing for dataset, and $>1,0 \rightarrow$ application of logarithmic change.

For better interpolation with the kriging technique, it is required to select the best semivariogram models from five models, such as: spherical, exponential, linear, Gaussian and rational quadratic [60]. Exponential models were fitted to the experimental semivariograms for the $\mathrm{pH}, \mathrm{EC}, \mathrm{OC}, \mathrm{K}, \mathrm{Zn}$, Sand, Silt and Clay, whereas N and P values best suited to the Gaussian model (Figure 3, Table 4). The Gaussian model is generally used for large range of data (i.e. Phosphorous ranges from 35 to $230 \mathrm{ppm}$ ) for interpolation operation [61]. Comparing range values, highest value was observed for EC $(1088.9 \mathrm{~m})$ and lowest for P (53.589 m). Nuggets were highest for available potassium $(\mathrm{K})$ and lowest for soil organic carbon (OC). 


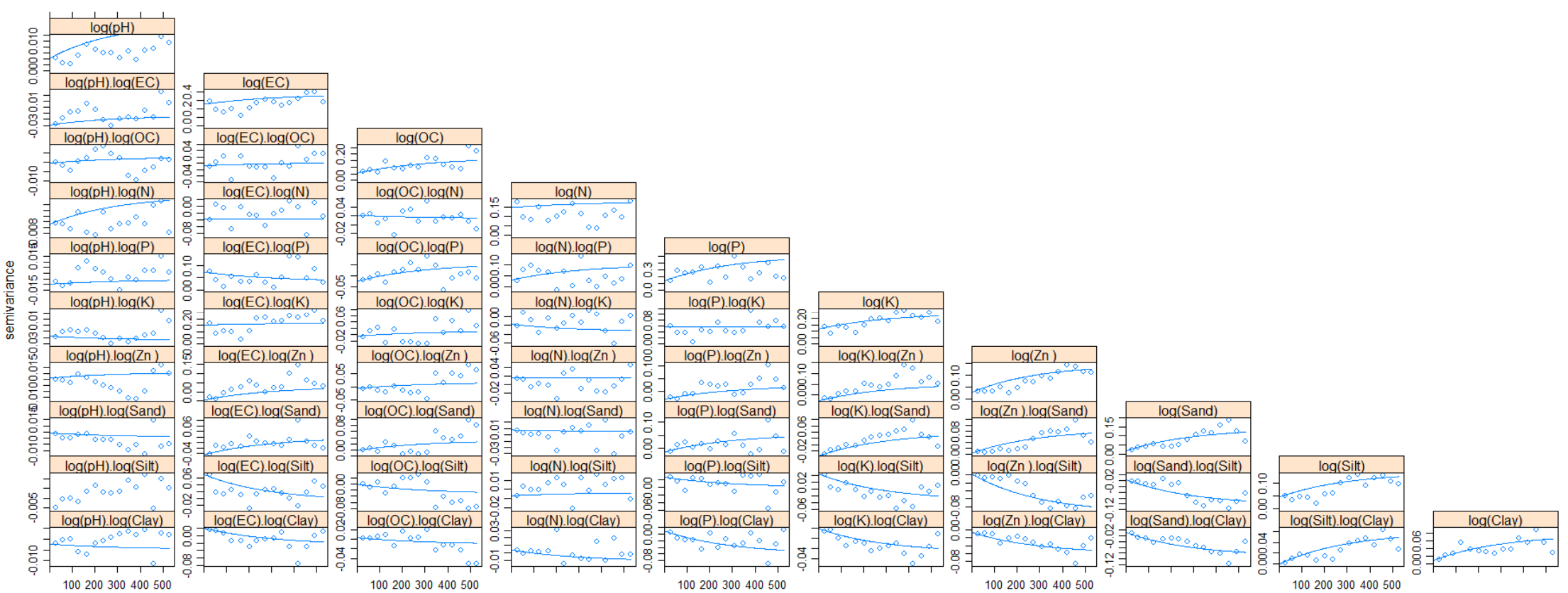

100200300400500

100200300400500

100200300400500

100200300400500

10020030040050

Figure 3. System comparison of variograms and cross-variograms for soil pH, EC, OC, N, P, K, Zn, sand, silt and clay in the study area. 
Table 4. Summary of semivariogram parameters of best-fitted theoretical model to predict spatial variability of soil nutrient parameters and cross-validation statistics $(n=70)$.

\begin{tabular}{|c|c|c|c|c|c|c|c|c|c|c|c|}
\hline \multirow{2}{*}{ Parameters } & \multirow{2}{*}{ Model } & \multirow{2}{*}{$\mathrm{C}_{0}$} & \multirow{2}{*}{$\mathrm{C}_{1}$} & \multirow{2}{*}{$\mathrm{C}_{0}+\mathrm{C}_{1}$} & \multirow{2}{*}{$\mathbf{A}_{0}$} & \multirow{2}{*}{$\begin{array}{c}\text { DSD } \\
(\%)\end{array}$} & \multirow{2}{*}{ SD } & \multicolumn{4}{|c|}{ Estimated Error } \\
\hline & & & & & & & & MSE & ASE & RMSE & RMSSE \\
\hline Log $\mathrm{pH}$ & Exponential & 0.064 & 0.086 & 0.149 & 459 & 42.54 & M & -0.01 & 0.32 & 0.34 & 1.05 \\
\hline OC $(\%)$ & Exponential & 0.006 & 0.018 & 0.024 & 542.4 & 24.99 & $\mathrm{~S}$ & -0.005 & 0.11 & 0.12 & 1.09 \\
\hline $\mathrm{N}(\mathrm{ppm})$ & Gaussian & 66.147 & 16.636 & 82.783 & 804.0 & 79.90 & W & -0.002 & 9.08 & 10.07 & 1.10 \\
\hline$P(p p m)$ & Gaussian & 4.939 & 4939.8 & 4944.73 & 53.58 & 0.099 & $\mathrm{~S}$ & -0.10 & 106.9 & 79.57 & 0.92 \\
\hline Sand $(\%)$ & Exponential & 20.79 & 170.7 & 191.553 & 846.6 & 10.85 & $S$ & -0.01 & 7.65 & 7.80 & 1.02 \\
\hline Silt (\%) & Exponential & 7.405 & 24.83 & 32.238 & 633.2 & 22.97 & $S$ & -0.003 & 4.23 & 3.99 & 0.98 \\
\hline Clay (\%) & Exponential & 16.53 & 72.87 & 89.413 & 931.4 & 18.49 & $S$ & -0.02 & 6.07 & 5.71 & 1.08 \\
\hline
\end{tabular}

Note: $\mathrm{C}_{0}=$ nugget effect; $\mathrm{C}_{1}=$ partial sill; $\mathrm{C}_{0}+\mathrm{C}_{1}=$ sill; $\mathrm{A}_{0}=$ Range $(\mathrm{m})$; degree of spatial dependence $(\mathrm{DSD})=\mathrm{C}_{0} /\left(\mathrm{C}_{0}\right.$ $+\mathrm{C}_{1}$ ) DSD; $\mathrm{S}=$ strong DSD $(<25 \%) ; \mathrm{M}=$ moderate DSD ( $>25$ to $\left.<75 \%\right) ; \mathrm{W}=$ weak DSD $(>75 \%)$. SD: Spatial dependence; ASE: Average standard error; RMS: Root mean squared error; MSE: Mean standard error; RMSSE: Root-mean-square standardized error.

According to this classification, OC, P, Zn, sand, silt and clay showed a strong spatial dependence; $\mathrm{pH}, \mathrm{EC}$ and $\mathrm{K}$ exhibited moderate spatial dependence, and only $\mathrm{N}$ showed weak degree spatial dependence of (Table 4). Cross-validation was used to estimate the best models to give the most accurate predictions of the unknown values in the study area. It was shown that the error terms ME (mean error) and MSE (mean standard error) were close to zero for EC, OC, N and silt. However, soil texture type was used instead of sand, silt or clay \% values for interpolation analysis.

\subsection{AHP Weightage Estimation}

Some studies [62] have utilized the effect of individual parameters on crop yield, to define their importance on crop production. However, the impact of a single parameter on the crop yield is minimal and the regression curves are very insignificant. Hence, the technique of ranking parameters with regression co-efficient was not followed [63]. Ranking was carried out based on the opinion of experts from relevant specializations.

\subsection{Kharif Crop Suitability Analysis}

Rice and jute are the major crops during Kharif season in the study area. The pairwise comparison matrix table gave highest weightage value to soil texture (ST) and lowest weightage value of available zinc $(\mathrm{Zn})$ for the rice crop (Table 5), where as for jute, $\mathrm{pH}$ was given highest weightage value and available potassium (K) was given lowest weightage value (Table 6).

Table 5. Pair wise comparison matrix and eigenvector of criteria in analytical hierarchy process (AHP) for rice crop $(n=8)$.

\begin{tabular}{cccccccccc}
\hline & $\mathbf{S T}$ & $\mathbf{p H}$ & $\mathbf{E C}$ & $\mathbf{O C}$ & $\mathbf{N}$ & $\mathbf{P}$ & $\mathbf{K}$ & $\mathbf{Z n}$ & Weightage \\
\hline $\mathrm{ST}$ & 1 & 2 & 3 & 3 & 5 & 7 & 7 & 9 & 0.311 \\
$\mathrm{pH}$ & 0.5 & 1 & 2 & 2 & 5 & 7 & 7 & 8 & 0.227 \\
$\mathrm{EC}$ & 0.333 & 0.5 & 1 & 2 & 4 & 6 & 6 & 7 & 0.171 \\
$\mathrm{OC}$ & 0.333 & 0.5 & 0.5 & 1 & 3 & 4 & 4 & 6 & 0.122 \\
$\mathrm{~N}$ & 0.2 & 0.2 & 0.25 & 0.333 & 1 & 3 & 3 & 5 & 0.07 \\
P & 0.142 & 0.142 & 0.167 & 0.25 & 0.333 & 1 & 2 & 4 & 0.043 \\
K & 0.142 & 0.142 & 0.167 & 0.25 & 0.333 & 0.5 & 1 & 4 & 0.037 \\
Zn & 0.111 & 0.125 & 0.142 & 0.167 & 0.2 & 0.25 & 0.25 & 1 & 0.019 \\
\hline
\end{tabular}

Note: consistency index $\left(\lambda_{\max }\right)=8.75$, Random inconsistency index $(\mathrm{RI})=1.41$, consistency index $(\mathrm{CI})=0.11$; consistency ratio $(\mathrm{CR})=0.08(<0.10)$. ST—-soil texture, $\mathrm{OC}$ - organic carbon, $\mathrm{N}$-available nitrogen, $\mathrm{P}$-available phosphorous, $\mathrm{K}$-available potassium, $\mathrm{Zn}$-zinc level, $\mathrm{n}$-no. of parameters. 


\subsubsection{Rice}

Rice is a major staple food for the rural population in West Bengal, India. It is mainly cultivated by small farmers with farm holdings of less than 1 hectare during the Kharif season. The rice suitability map of the study area (Figure 4 ) showed that nearly $29.2 \%$ of the area is 'highly suitable' $\left(\mathrm{S}_{1}\right), 51.2 \%$ area is 'marginal suitable' $\left(\mathrm{S}_{3}\right)$ and nearly $13 \%$ of area is 'not suitable' $(\mathrm{N})$, (Figure 4). Nearly, $85.5 \%$ of the farms also found sound for suitable rice, as the study area is a major rice-growing zone in the region.

The unsuitable area, where soils have some rice growth limitations, such as the presence of acidic soil ( $\mathrm{pH}$ value $<5.5$ ). The soil may be treated with lime or different soil strengthening material for growing rice profitably. However, these areas may be allotted alternative crops. For better assessment of rice yield, various advanced techniques may be used, such as, aerial photography, image processing [64], low altitude remote sensing [65] and satellite-based remote sensing etc.

Table 6. Pair wise comparison matrix and eigenvector of criteria in AHP for jute crop $(n=8)$.

\begin{tabular}{cccccccccc}
\hline & $\mathbf{p H}$ & $\mathbf{S T}$ & $\mathbf{N}$ & $\mathbf{Z n}$ & $\mathbf{O C}$ & $\mathbf{E C}$ & $\mathbf{P}$ & $\mathbf{K}$ & Weightage \\
\hline $\mathrm{pH}$ & 1 & 2 & 3 & 4 & 5 & 5 & 6 & 7 & 0.317 \\
$\mathrm{ST}$ & 0.5 & 1 & 2 & 3 & 4 & 4 & 5 & 6 & 0.218 \\
$\mathrm{~N}$ & 0.333 & 0.5 & 1 & 2 & 4 & 4 & 5 & 5 & 0.165 \\
$\mathrm{Zn}$ & 0.25 & 0.333 & 0.5 & 1 & 2 & 2 & 4 & 5 & 0.105 \\
$\mathrm{OC}$ & 0.2 & 0.25 & 0.25 & 0.5 & 1 & 1 & 3 & 5 & 0.072 \\
$\mathrm{EC}$ & 0.2 & 0.25 & 0.25 & 0.5 & 1 & 1 & 2 & 3 & 0.06 \\
$\mathrm{P}$ & 0.167 & 0.2 & 0.2 & 0.25 & 0.333 & 0.5 & 1 & 2 & 0.037 \\
$\mathrm{~K}$ & 0.142 & 0.167 & 0.2 & 0.2 & 0.2 & 0.333 & 0.5 & 1 & 0.026 \\
\hline
\end{tabular}

Note: $\lambda_{\max }=8.53, \mathrm{RI}=1.41, \mathrm{CI}=0.08 ; \mathrm{CR}=0.05(<0.10)$. ST-soil texture, OC-organic carbon, $\mathrm{N}$-available nitrogen, $\mathrm{P}$-available phosphorous, $\mathrm{K}$-available potassium, $\mathrm{Zn}$-zinc level, $\mathrm{n}$-no. of parameters.

\subsubsection{Jute}

Jute is an important major deep rooted cash crop grown under irrigated conditions in the study area. About $6.5 \%$ and $56 \%$ of total farm areas are classified as 'highly suitable' $\left(\mathrm{S}_{1}\right)$, and 'moderate suitable' $\left(\mathrm{S}_{2}\right)$ groups, respectively. Nearly $2.1 \%$ of the area is found under 'not suitable' $(\mathrm{N})$ class for jute crop. So, nearly $62 \%$ of the land area was classified under suitable range (Figure 4 ) may replace rice area giving low yield. The major limitations for crop growth reported for these soils were low organic matter and nitrogen content and acidic $\mathrm{pH}$.

\subsection{Rabi Crop Suitability Analysis}

Potato and lentil are the major crops during Rabi season in the study area. The pairwise comparison matrix table gave highest weightage value of available potassium $(\mathrm{K})$ and lowest weightage value of available zinc (Zn) for potato crops (Table 7), whereas for lentils, soil texture (ST) was given highest weightage value and available nitrogen $(\mathrm{N})$ was given lowest weightage values (Table 8 ). 
Table 7. Pair wise comparison matrix and eigenvector of criteria in AHP for potato crop $(n=8)$.

\begin{tabular}{cccccccccc}
\hline & $\mathbf{K}$ & $\mathbf{S T}$ & $\mathbf{N}$ & $\mathbf{p H}$ & $\mathbf{O C}$ & $\mathbf{E C}$ & $\mathbf{P}$ & $\mathbf{Z n}$ & Weightage \\
\hline $\mathrm{K}$ & 1 & 2 & 3 & 4 & 5 & 6 & 7 & 8 & 0.326 \\
$\mathrm{ST}$ & 0.5 & 1 & 2 & 3 & 4 & 4 & 6 & 6 & 0.217 \\
$\mathrm{~N}$ & 0.333 & 0.5 & 1 & 2 & 3 & 3 & 5 & 6 & 0.15 \\
$\mathrm{pH}$ & 0.25 & 0.333 & 0.5 & 1 & 3 & 3 & 5 & 5 & 0.119 \\
$\mathrm{OC}$ & 0.2 & 0.25 & 0.333 & 0.333 & 1 & 2 & 4 & 4 & 0.075 \\
$\mathrm{EC}$ & 0.167 & 0.25 & 0.333 & 0.333 & 0.5 & 1 & 3 & 3 & 0.056 \\
P & 0.142 & 0.167 & 0.2 & 0.2 & 0.25 & 0.333 & 1 & 2 & 0.032 \\
$\mathrm{Zn}$ & 0.125 & 0.167 & 0.167 & 0.2 & 0.25 & 0.333 & 0.5 & 1 & 0.025
\end{tabular}

Note: $\lambda_{\max }=8.60, \mathrm{RI}=1.41, \mathrm{CI}=0.09 ; \mathrm{CR}=0.06(<0.10)$. ST—soil texture, OC—organic carbon, $\mathrm{N}$-available nitrogen, $\mathrm{P}$-available phosphorous, $\mathrm{K}$-available potassium, $\mathrm{Zn}$-zinc level, $\mathrm{n}$-no. of parameters.

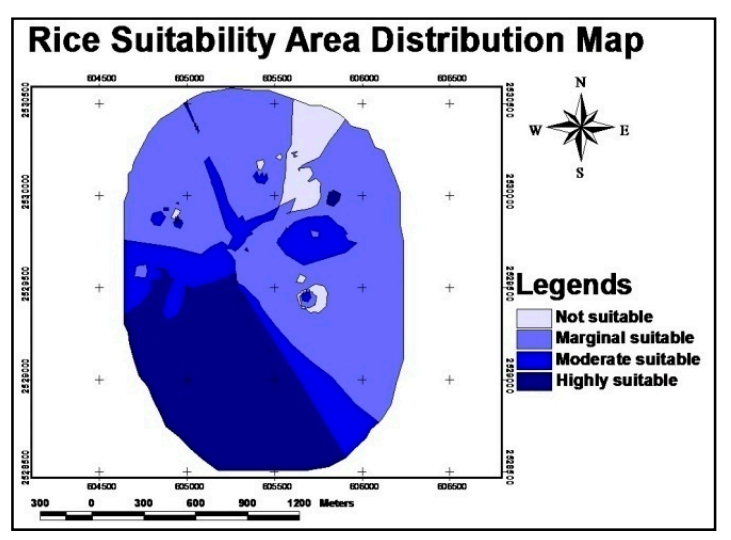

(a)

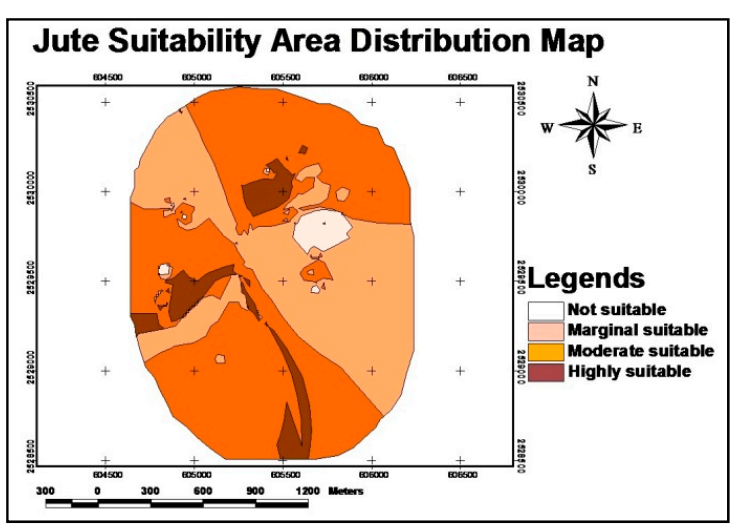

(b)

Figure 4. Kharif crops suitability distribution maps; (a) rice, (b) jute.

Table 8. Pair wise comparison matrix and eigenvector of criteria in AHP for lentil crop $(n=8)$.

\begin{tabular}{cccccccccc}
\hline & ST & pH & Zn & EC & OC & P & K & N & Weightage \\
\hline ST & 1 & 2 & 3 & 5 & 6 & 7 & 8 & 8 & 0.345 \\
pH & 0.5 & 1 & 2 & 3 & 3 & 5 & 7 & 8 & 0.218 \\
Zn & 0.333 & 0.5 & 1 & 2 & 3 & 4 & 5 & 7 & 0.153 \\
EC & 0.2 & 0.333 & 0.5 & 1 & 2 & 3 & 5 & 6 & 0.107 \\
OC & 0.167 & 0.333 & 0.333 & 0.5 & 1 & 2 & 4 & 5 & 0.077 \\
P & 0.142 & 0.2 & 0.25 & 0.333 & 0.5 & 1 & 2 & 3 & 0.046 \\
K & 0.125 & 0.142 & 0.2 & 0.2 & 0.25 & 0.5 & 1 & 3 & 0.033 \\
N & 0.125 & 0.125 & 0.142 & 0.167 & 0.2 & 0.333 & 0.333 & 1 & 0.021 \\
\hline
\end{tabular}

Note: $\lambda_{\max }=8.53, \mathrm{RI}=1.41, \mathrm{CI}=0.08 ; \mathrm{CR}=0.05(<0.10)$. ST—soil texture, OC—organic carbon, N-available nitrogen, $\mathrm{P}$-available phosphorous, $\mathrm{K}$-available potassium, $\mathrm{Zn}$ - zinc level, $\mathrm{n}$-no. of parameters.

\subsubsection{Potato}

During the field visit, potato was found to be one of the dominant crops in the study area during the Rabi season. Under irrigation conditions, potato gives sound yield in the study area. The land suitability study divided the farms into four classes (Figure 5). Nearly $21.3 \%$ area is under the 'highly suitable' $\left(S_{1}\right)$ class and $67.3 \%$ under the 'moderately suitable' class $\left(S_{2}\right)$, (Table 9). The first two suitable classes occupy a total area of $88.6 \%$ (256 ha), which proves the dominance of the crop in the study area. High EC, low $\mathrm{pH}$ and organic carbon are the major limitations of this area, which can be improved by adopting specific management practices. 


\subsubsection{Lentil}

Lentil is an important pulse crop grown in the Rabi season in West Bengal. Lentil suitability distribution map (Figure 5) revealed that $12.4 \%$ of the total area is 'highly suitable' $\left(\mathrm{S}_{1}\right)$, for the crop, whereas $54.6 \%$ was 'moderately suitable' $\left(\mathrm{S}_{2}\right)$, (Table 9 ). Nearly $30 \%$ area was under 'marginal suitable' $\left(\mathrm{S}_{3}\right)$ class and 3\% were under 'not suitable' $(\mathrm{N})$ class. Together, the two categories 'highly suitable' and 'moderately suitable' make up $67 \%$ of the total area. The analysis also depicted that physical and environmental conditions of the study area were mostly suited to potato cultivation.

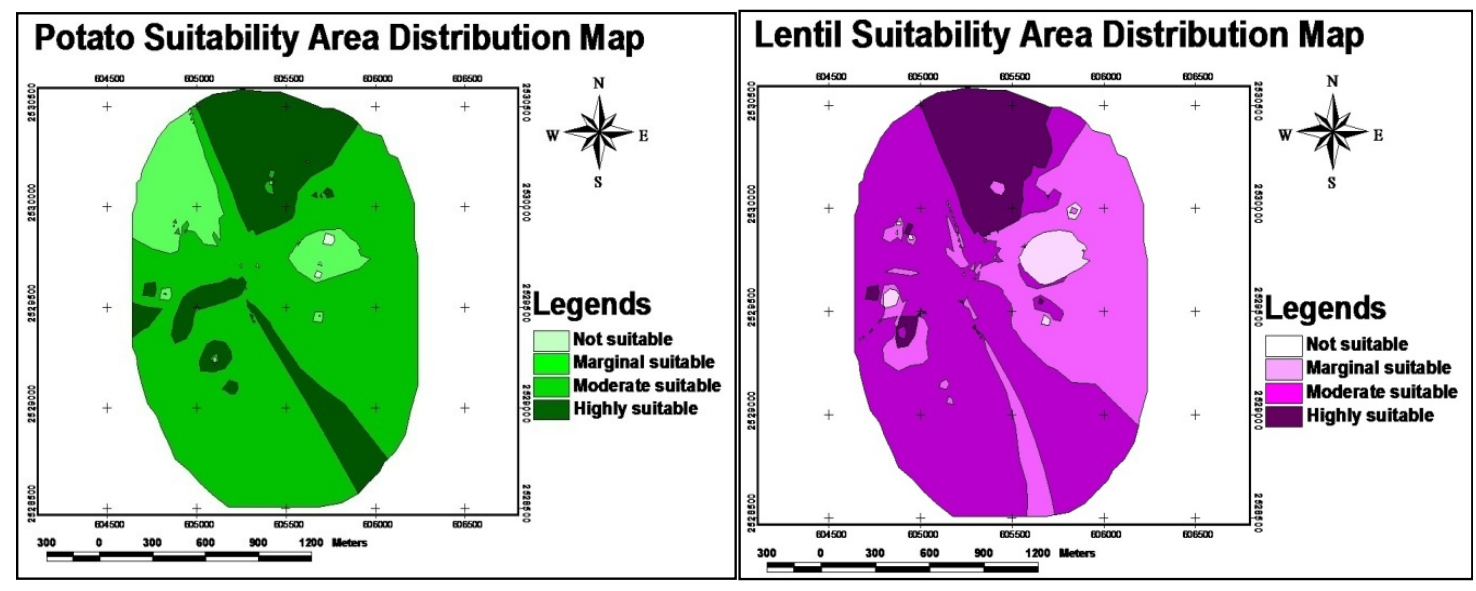

(a)

(b)

Figure 5. Rabi season crops suitability distribution maps; (a) potato, (b) lentil.

\subsection{Crop Yield Mapping and Validation}

Yield distribution map for currently grown crops, such as rice and potato, were developed with the yield information collected for each plot during the soil sample collection. In terms of crop yield, nearly $75 \%$ and $90 \%$ area found sound for growing rice and potato crops, respectively, in the study area (Figure 6). It may be one of the major reasons of farmers' inclination towards rice-potato crop rotation system in the region. These maps were compared with the suitability distribution map of the corresponding crops.

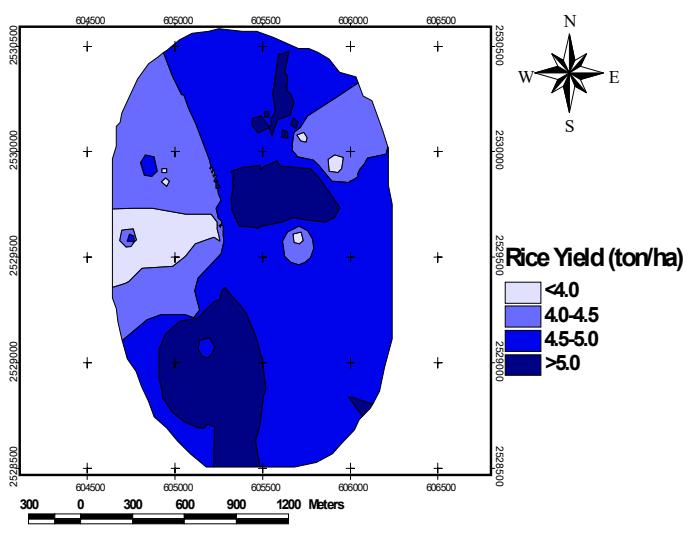

(a)

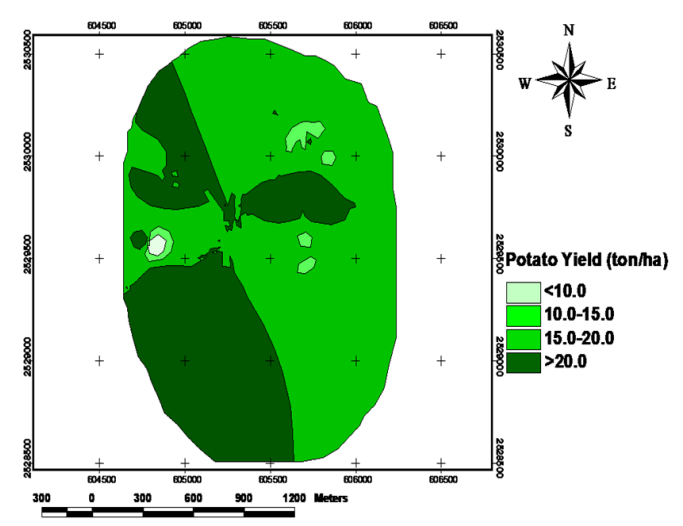

(b)

Figure 6. Yield distribution map of study area; (a) rice crop, (b) potato crop. 
Comparing the rice yield map with rice suitability distribution map, showed the area under the highly suitable class (Figure 4a) produced highest crop yield (Figure 6a) in the range of 5 ton/ha or higher. Additionally, some areas under marginal suitable class give moderate crop yield along with the area distributed under the moderately suitable class. For potato crops, majority of the study area was classified as moderate suitable, which gave moderate crop yield in a range of 15 to 20 ton/ha. These yield maps validated the suitability distribution map developed based on various soil nutrient parameters using the AHP-GIS technique.

\subsection{Crop Rotations}

The pattern of crops or sequence in which the crops are cultivated on a piece of land over a fixed period of a year defines a cropping pattern. Analysis by AHP-GIS techniques reflected that rice and jute are two major crops in the Kharif season and rice is currently preferred throughout the study area. Similarly, potato and lentil are the two major crops during the Rabi season and potato is mostly concentrated throughout the study area as well as the region. Crop rotation, the sequential planting of crops, indicates that the Tarakeswar block has the major crop rotations of rice/jute and potato/lentil (Table 9). Consequently, the results obtained from the study indicated that the use of AHP in the GIS software environment could provide a superior database and guide map for decision makers for precision agriculture adoption through crop rotation.

Table 9. Land suitability distribution for Kharif and Rabi season crops.

\begin{tabular}{cccccc}
\hline \multirow{2}{*}{ Class } & \multirow{2}{*}{ Description } & \multicolumn{2}{c}{ Kharif (\% of Area) } & \multicolumn{2}{c}{ Rabi (\% of Area) } \\
\cline { 3 - 6 } & & Rice & Jute & Potato & Lentil \\
\hline $\mathrm{S}_{1}$ & Highly suitable & 29.2 & 6.5 & 21.3 & 12.4 \\
$\mathrm{~S}_{2}$ & Moderate suitable & 15.1 & 56.0 & 67.3 & 54.6 \\
$\mathrm{~S}_{3}$ & Marginal suitable & 51.2 & 35.4 & 11.3 & 30.0 \\
$\mathrm{~N}$ & Not suitable & 4.5 & 2.1 & 0.1 & 3.0 \\
\hline
\end{tabular}

\subsection{Crop Recommendation}

Using the 'Map Query' tool in Arc GIS 10.1, analysis was carried out to find the suitable crop for areas classified as 'unsuitable' for rice crops. Using the application, jute crop was recommended for the area, earn-marked as 'unsuitable' for rice crop but classified as 'suitable' for jute crop (Figure 7). Nearly $25 \%$ of the area classified as unsuitable for rice crop can be grown jute with great success (Table 10). Therefore, for the Kharif season crop rotational practice, we recommended the rice area ( $25 \%$ or around 74 ha) be allotted to jute crop as an alternative providing better economic benefit.

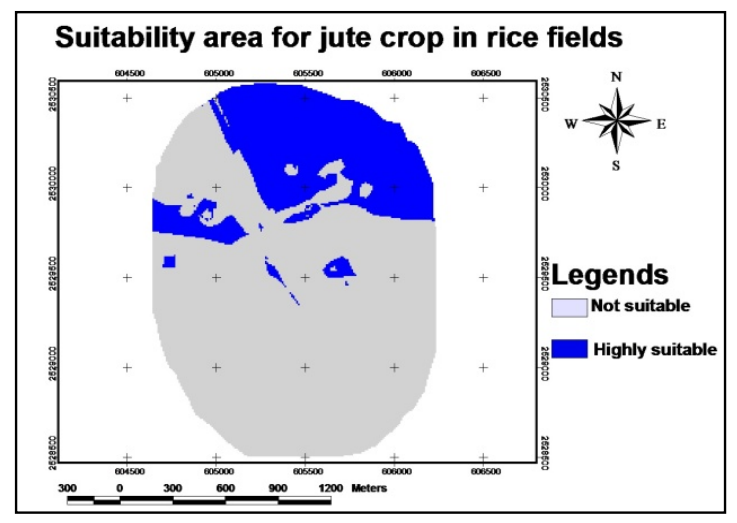

(a)

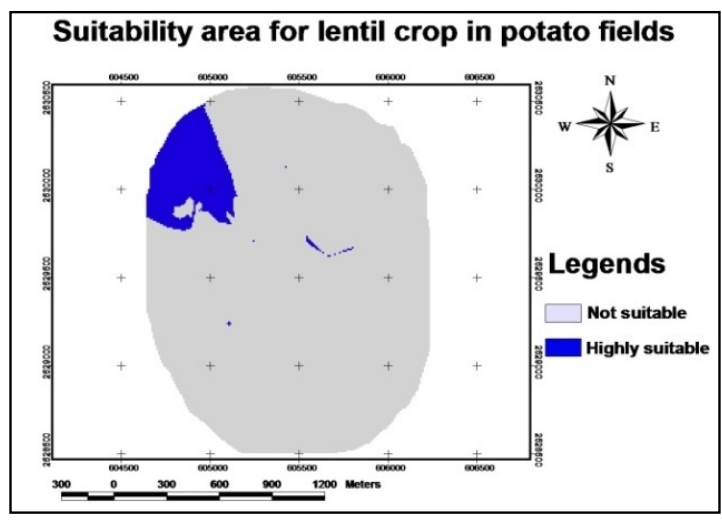

(b)

Figure 7. Crop recommendation based on suitable area distribution analysis; (a) jute in rice area, (b) lentil in potato area. 
Table 10. Crop recommendation based on suitability analysis.

\begin{tabular}{cccccc}
\hline Sl. No. & Description & Area (ha) & (\% of Area) & Current Crop & Recommended Crop \\
\hline \multicolumn{7}{c}{} & \multicolumn{5}{c}{ Kharif crop } \\
I & Highly suitable & 217 & 75 & Rice & Rice \\
II & Not suitable & 74 & 25 & Rice & Jute \\
\hline \multicolumn{7}{r}{} & & Rabi crop & \\
III & Highly suitable & 267 & 92 & Potato & Potato \\
IV & Not suitable & 24 & 8 & Potato & Lentil \\
\hline
\end{tabular}

Similarly, the area unsuitable for potato crop but classified as suitable for lentil crop were recommended for growing lentil in Rabi season (Figure 7). The amount of area recommended for the potato crop and for lentil crop was $92 \%$ and $8 \%$, respectively (Table 7). So, in the Rabi season, the lentil crop was suggested as an alternative for growing with better crop yield and profit margin in $8 \%$ of the area found unsuitable for the potato crop.

Therefore, it can be strongly recommended that the crop land suitability classes must be considered for allocation land to new alternative crops, using GIS-AHP techniques.

\section{Discussion}

The study area is the leading producer of potato as well as rice being located in the fertile Hooghly river basin of West Bengal. The majority of the farms in the study area are following rice-potato crop rotation for a long time. However, due to low crop yield (rice crop) and reduced profit margin (potato crop) for the farmers, land suitability evaluation for the best crop rotation is required for the study area and its surrounding region. Low price of potato during harvesting time along with unavailability of cold storage has drastically reduced the return to the farmers. Also, traditional rice varieties with the age-old cropping system have substantially reduced the crop yield and profit.

Land suitability evaluation is a powerful tool to support decision-making in land-use planning; it deals with the assessment of the response of land when used for specified purposes. The AHP-GIS technique has been used to find the best suited crop for a piece of land. As farmers are growing nearly 2-3 crops per year, it is required to select the best crop combination using this technique. Two set of crops (rice-jute for Kharif and potato-lentil crop for Rabi) were evaluated for suitability in 70 farm plots in Hooghly, West Bengal, India. Descriptive statistical models gave preliminary but vital information on data values, their variation and presence of outliers. Overall, the availability of organic carbon in the range of $0.5 \%$ is low for growing crops. A semivariogram model depicts the spatial autocorrelation of the data values by range, sill and nuggets of a fitted model. Among the semivariogram models, exponential models were fitted well for the $\mathrm{pH}, \mathrm{EC}, \mathrm{OC}, \mathrm{K}, \mathrm{Zn}$, sand, silt and clay and Gaussian models for $\mathrm{N}$ and $\mathrm{P}$ parameters for the study area. Cross-validation was used to estimate and select best suited semivariogram models to give the most accurate predictions of the unknown values through kriging interpolation in the study area.

The yield map showed nearly $75 \%$ of rice and $95 \%$ of potato growing areas gave good crop yield. This may be the reason why farmers are still following rice-potato crop rotation. Land suitability evaluation was carried out using the AHP-based weighting for the nutrients for the crops such as rice, jute, potato and lentil. The area classified as suitable (under highly suitable and moderately suitable) class with AHP (Figures 4 and 5), gave sound yield (Figure 6) for both rice and potato crops in the study area. This validated the suitability of the AHP-GIS technique for land suitability analysis. The suitability distribution map showed jute was suitable for 62\% (180 ha) and lentil for 67\% (195 ha) of the study area. Therefore, we have alternative crops for (both Kharif and Rabi seasons) to replace the traditional crops.

Although the majority of the area found suitable for rice-potato crop rotation pattern, the areas which are unsuitable for rice may be dedicated for jute crop (Kharif season) and potato area for lentil 
crop (Rabi season) as an alternative in the region. The area recommended for jute and lentil were selected using the "Map Query" application in the Arc GIS software environment. Similar study by Mustafa et al. [66] carried out for various Kharif crops in Agra, U.P., India, to map suitable areas for crops such as cotton, rice, maize and sorghum etc. and Rabi crops such as mustard, wheat etc. However, the best crop rotation was not suggested. Marraccini et al. [67] used the land suitability technique to introduce new crops in northern France ensuring better profit to the farmers. A similar strategy can be used to allocate new crops in areas unsuitable for currently raised crops or varieties.

On the basis of the above discussions and findings, the study explored a simple but effective way to use AHP-GIS for land suitability crop mapping and major crop rotation identification by analyzing the crop dynamics in a spatial and quantitative way.

\section{Conclusions}

The present study introduces a method for analyzing the cropping systems for main crops and alternative crops. Two season crop rotational maps were derived using a GIS overlay technique with an AHP decision support system. The land suitability evaluation based on various soil nutrients, derived from the GIS overlay technique with AHP, computed that only $29.2 \%$ of the study area is 'highly suitable' for rice, and $67.3 \%$ area is 'moderate suitable' for potato. Additionally, $62 \%$ and $67 \%$ area is found suitable for jute and lentil, respectively. The yield maps showed nearly $75 \%$ and $90 \%$ of the area for rice and potato crops, respectively, gave sound crop yields. The 'moderate' to 'marginal' suitability class of $\left(\mathrm{S}_{2}-\mathrm{S}_{3}\right)$ was mostly found all over the plain, for irrigated rice, potato, jute and lentil cultivation.

GIS-AHP based land suitability can be extended to select alternative crops. The study recommended $25 \%$ unsuitable rice area for jute crops in Kharif and $8 \%$ unsuitable potato area for lentils as Rabi crop cultivation.

Author Contributions: Conceptualization, C.S. and K.C.S.; methodology, K.C.S.; software, K.C.S.; validation, C.S., K.C.S. and S.K.S.; formal analysis, C.S.; investigation, S.K.S.; resources, C.S.; writing-original draft preparation, K.C.S.; writing-review and editing, S.K.S.; visualization, S.K.S.; supervision, K.C.S. All authors have read and agreed to the published version of the manuscript.

Funding: This research received no external funding.

Acknowledgments: The authors like to acknowledge the contribution of Institute of Agriculture, Visva-Bharati for facilitating this research work.

Conflicts of Interest: The authors declare that no conflict of interest exists with this research work.

\section{References}

1. IBEF Report. Culturally Artistic, Indian Brand Equity Foundation: West Bengal, India. 2017. Available online: https://www.ibef.org/download/West-Bengal-July-2017.pdf (accessed on 10 April 2020).

2. Sarkar, D. Study on growth of major cereals in West Bengal. Econ. Aff. 2014, 60, 161-167. [CrossRef]

3. Roy, S. Farm distress: Why the potato isn't hot in Bengal this season. Business line-The Hindu, 8 January 2018.

4. Ghosal, S. West Bengal to produce 10\% higher potatoes this year. Economic Times, 10 January 2020.

5. FAO. A Frame Work for Land Suitability Study for Irrigated Agriculture; FAO: Rome, Italy, 1993.

6. Bontikes, T.S.; Keulen, H.V. Modelling the dynamics of agricultural development at farm and regional level. Agric. Syst. 2003, 76, 379-396. [CrossRef]

7. Casasnovas, M.J.; Martin-Monetero, A.; Casterad, M.A. Mapping multi-year cropping patterns in small irrigation districts from time series analysis of Landsat TM images. Eur. J. Agron. 2005, 23, 159-169. [CrossRef]

8. Jamil, M.; Sajjad, H. Deriving cropping system efficiency pattern using remote sensing and GIS: A case study of Bijnor district, India. Int. J. Adv. Remote Sens. GIS Geogr. 2016, 4, 27-40.

9. Khahro, S.H.; Matori, A.N.; Chandio, I.A.; Talpur, M.A.H. Land suitability analysis for installing new petrol filling stations using GIS. Procedia Eng. 2014, 77, 28-36. [CrossRef]

10. Singha, C.; Swain, K.C. Land Suitability Evaluation Criteria for Agricultural crop selection: A Review. Agric. Rev. 2016, 37, 125-132. [CrossRef] 
11. Kuria, D.; Ngari, D.; Withaka, E. Using geographic information systems (GIS) to determine land suitability for rice crop growing in the Tana delta. J. Geogr. Reg. Plan. 2011, 4, 525-532.

12. Feizizadeh, B.; Jankowski, P.; Blaschke, T. A GIS based spatially explicit sensitivity and uncertainty analysis approach for multicriteria decision analysis. Comput. Geosci. 2014, 64, 81-95. [CrossRef]

13. Montgomery, B.; Dragićević, S.; Dujmović, J.; Schmidt, M. A GIS-based Logic Scoring of Preference method for evaluation of land capability and suitability for agriculture. Comput. Electron. Agric. 2016, 124, 340-353. [CrossRef]

14. Collins, M.G.; Steiner, F.R.; Rushman, M.J. Landuse suitability analysis in the United States: Historical development and promising technological achievements. Environ. Manag. 2001, 28, 611-621. [CrossRef]

15. Mendas, A.; Delali, A. Integration of multi-criteria decision analysis in GIS to develop land suitability for agriculture: Application to durum wheat cultivation in the region of Mleta in Algeria. Comput. Electron. Agric. 2012, 83, 117-126. [CrossRef]

16. Zolekar, R.B.; Bhagat, V.S. Multi-criteria land suitability analysis for agriculture in hilly zone: Remote sensing and GIS approach. Comput. Electron. Agric. 2015, 118, 300-321. [CrossRef]

17. Yalew, S.G.; van Griensven, A.; van der Zaag, P. AgriSuit: A web-based GIS-MCDA framework for agricultural land suitability assessment. Comput. Electron. Agric. 2016, 128, 1-8. [CrossRef]

18. Swain, K.C.; Jayasuriya, H.P.W.; Salokhe, V.M. Low altitude remote sensing (LARS): A potential substitution to satellite based remotes sensing for precision agriculture adoption in fragmented and diversified farming conditions. Agric. Eng. Int. CIGR Ej. 2009, 9, 1-16.

19. Saaty, T.L. The Analytic Hierarchy Process: Planning, Priority Setting, Resource Allocation; McGraw-Hill International: New York, NY, USA, 1980.

20. Nefeslioglu, H.A.; Sezer, E.A.; Gokceoglu, C.; Ayas, Z. A modified analytical hierarchy process (M-AHP) approach for decision support systems in natural hazard assessments. Comput. Geosci. 2013, 59, 1-8. [CrossRef]

21. Zabihi, H.; Ahmad, A.; Vogeler, I.; Said, M.N.; Golmohammadi, M.; Golein, B.; Nilashi, M. Land suitability procedure for sustainable citrus planning using the application of the analytical network process approach and GIS. Comput. Electron. Agric. 2015, 117, 114-126. [CrossRef]

22. Mishra, A.K.; Deep, S.; Choudhary, A. Identification of suitable sites for organic farming using AHP \& GIS. Egypt. J. Remote Sens. Space Sci. 2015, 18, 181-193.

23. Akinci, H.; Ozalp, A.Y.; Turgut, B. Agriculture land use suitability analysis using GIS and AHP technique. Comput. Electron. Agric. 2013, 97, 71-82. [CrossRef]

24. Zhang, J.; Su, Y.; Wu, J.; Liang, H. GIS based land suitability assessment for tobacco production using AHP and fuzzy set in Shandong province of China. Comput. Electron. Agric. 2015, 114, 202-211. [CrossRef]

25. Boroushaki, S.; Malczewski, J. Implementing an extension of the analytical hierarchy process using ordered weighted averaging operators with fuzzy quantifiers in ArcGIS. Comput. Geosci. 2008, 34, 399-410. [CrossRef]

26. Hamzeh, S.; Mokarram, M.; Haratian, A.; Bartholomeus, H.; Ligtenberg, A.; Bregt, A.K. Feature Selection as a Time and Cost-Saving Approach for Land Suitability Classification (Case Study of Shavur Plain, Iran). Agriculture 2016, 6, 52. [CrossRef]

27. Jayasinghe, S.L.; Kumar, L.; Sandamali, J. Assessment of Potential Land Suitability for Tea (Camellia sinensis(L.) O. Kuntze) in Sri Lanka Using a GIS-Based Multi-Criteria Approach. Agriculture 2019, 9, 148. [CrossRef]

28. Fekadu, E.; Negese, A. GIS assisted suitability analysis for wheat and barley crops through AHP approach at Yikalo sub-watershed, Ethiopia. Cogent Food Agric. 2020, 6, 1743623. [CrossRef]

29. Perveen, F.; Nagasawa, R.; Chongo, D.; Cherif, O.; Ahmed, A. Land Suitability Analysis for Rice Crop using Remote Sensing and GIS Technology. Jpn. Agric. Syst. Soc. 2017, 23, 283-295.

30. Widiatmaka. Integrated use of GIS, AHP and remote sensing in land use planning for tropical high altitude vegetable crops. J. Appl. Hortic. 2016, 18, 87-99. [CrossRef]

31. Kahsay, A.; Haile, M.; Gebresamuel, G.; Mohammed, M. Land suitability analysis for sorghum crop production in northern semi-arid Ethiopia: Application of GIS-based fuzzy AHP approach. Cogent Food Agric. 2018, 4, 1507184. [CrossRef]

32. Kumar, N.; Singh, S.K.; Mishra, V.N.; Obi Reddy, G.P.; Bajpai, R.K.; Saxena, R.R. Soil suitability evaluation for cotton using analytical hierarchic process. Int. J. Chem. Stud. 2018, 6, 1570-1576. 
33. NBBS and LUP. Soil Series of West Bengal; NBSS Publ. No. 89, NBSS and LUP (ICAR): Nagpur, India, 2001; pp. 38-40.

34. Soil Survey Division Staff. Soil Survey Manual (Indian Print); Hb. No. IS; USDA: Washington, DC, USA, 2000.

35. Halder, J.C. Land Suitability Assessment for Crop Cultivation by Using Remote Sensing and GIS. J. Geogr. Geol. 2013, 5, 65-74. [CrossRef]

36. Dwivedi, R.; Srivastva, P.C. Effect of zinc sulphate application and the cyclic incorporation of cereal straw on yields, the tissue concentration and uptake of $\mathrm{Zn}$ by crops and availability of $\mathrm{Zn}$ in soil under rice-wheat rotation. Int. J. Recycl. Org. Waste Agric. 2014, 3, 53. [CrossRef]

37. Joshi, D.; Srivastava, P.C.; Rama Dwivedi, R.; Pachauri, S.P. Chemical speciation of Zn in acidic soils: Suitable soil extractant for assessing Zn availability to maize (Zea mays L.). Chem. Speciat. Bioavailab. 2014, 26, 148-157. [CrossRef]

38. Jackson, M.L. Soil Chemical Analysis; Prentice Hall of India Pvt. Ltd: New Delhi, India, 1973.

39. Piper, C.S. Soils and Plant Analysis; The University of Adelaide: Adelaide, Australia, 1942.

40. USDA. Agricultural Research Service, Soil Texture Classification; Department of Biological System Engineering, Washington State University: Washington, DC, USA, 1980.

41. Lund, A.; Lund, M. Laerd Statistics: Descriptive and Inferential Statistics. 2018. Available online: https: //statistics.laerd.com/ (accessed on 15 May 2020).

42. Olea, R.A. TheSemivariogram. In Geostatistics for Engineers and Earth Scientists; Springer: Boston, MA, USA, 1999.

43. Cressie, N.; Zimmerman, D.L. On the stability of the geostatistical method. Math. Geol. 1992, $24,45-59$. [CrossRef]

44. Goulard, M.; Voltz, M. Linear coregionalization model: Tools for estimation and choice of cross-variogram matrix. Math. Geol. 1992, 24, 269-286. [CrossRef]

45. Granados, F.L.; Jurado-Exposito, M.; Atenciano, S.; Garcia-Ferrer, A.; De la Orden, M.S.; Garcia-Torres, L. Spatial Variability of Agricultural Soil Parameters in Southern Spain. Plant Soil 2002, 246, 97-105. [CrossRef]

46. Cambardella, C.A.; Moorman, T.B.; Novak, J.M.; Parkin, T.B.; Karlen, D.L.; Turco, R.F.; Konopka, A.E. Field-Scale Variability of Soil Properties in Central Iowa Soils. J. Soil Sci. Soc.Am. 1994, 58, 1501-1511. [CrossRef]

47. Diggle, P.J.; Ribeiro, P.J., Jr. Bayesian inference in Gaussian model-based geostatistics. Geogr. Environ. Model. 2002, 6, 129-146. [CrossRef]

48. Webster, R.; Oliver, M.A. Geostatistics for Environmental Scientists; John Wiley and Sons: Brisbane, Australia, 2001.

49. Kritikos, T.R.H.; Davies, T.R.H. GIS-based multi-criteria decision analysis for landslide susceptibility mapping at northern Evia, Greece. Z. Dtsch.Ges.Geowiss. 2011, 162, 421-434. [CrossRef]

50. Pramanik, M.K. Site suitability analysis for agricultural land use of Darjeeling district using AHP and GIS techniques. Model. Earth Syst. Environ. 2016, 2, 1-22. [CrossRef]

51. Saaty, T.L. A scaling method for priorities in hierarchical structures. J. Math. Psychol. 1977, 15, 57-68. [CrossRef]

52. Saaty, T.L.; Vargas, L.G. Prediction, Projection and Forecasting; Kluwer: Boston, MA, USA, 1991.

53. Prakash, N.T. Land Suitability Analysis for Agricultural Crops: A Fuzzy Multicriteria Decision Making Approach. Master's Thesis, International Institute for Geo Information Science and Earth Observation Enschede, Enschede, The Netherlands, 2003; pp. 1-57.

54. Dengiz, O.; Zyazici, M.A.; Saglam, M. Multi-criteria assessment and geostatistical approach for determination of rice growing suitability sites in Gokirmak catchment. Paddy Water Environ. 2013, 13, 1-10. [CrossRef]

55. Mongkolsawat, C.; Paiboonsak, S. GIS-Based Land Evaluation for Combining Economic Crops as a Model for Agricultural Land Use Planning. 2015. Available online: https://www.researchgate.net/publication/242162621 (accessed on 30 March 2018).

56. Samanta, S.; Pal, B.; Pal, D.K. Land suitability analysis for rice cultivation based on multi-criteria decision approach through GIS in, Morobe Province, Papua New Guinea. Int. J. Sci. Emerg. Technol. 2011, 2, 12-20.

57. NBBS \& LUP. Soil Resources of Tamil Nadu for Land Use Planning; Detailed Report Bangalore Centre, NBSS Publication: Bangalore, India, 1990.

58. Vinay, L. Characterization and Classification of Soil Resource of Bhanapur Microwatershed (Koppal District) for Land Evaluation. Ph.D. Thesis, University of Agricultural Sciences, Dharwad, India, 2007.

59. Mulla, D.J.; McBratney, A.B. Soil spatial variability. In Handbook of Soil Science; Sumner, M.E., Ed.; CRS Press: Boca Raton, FL, USA, 2000; pp. 321-352. 
60. Yan-bing, T. Comparison of semivariogram models for Kriging monthly rainfall in eastern China. J. ZhejUni-SCI A 2002, 3, 584-590. [CrossRef]

61. Kasa, S.R.; Bhattacharya, S.; Rajan, V. Gaussian Mixture Copulas for High-Dimensional Clustering and Dependency-based Subtyping. Bioinformatics 2019, 36, 621-628. [CrossRef] [PubMed]

62. Aimrun, W.; Amin, M.S.M.; Ezrin, M.H.; Mastura, M. Paddy soil properties and yield characteristics based on apparent electrical conductivity zone delineation for a humid tropical rice farm. Afr. J. Agric. Res. 2011, 6, 5339-5350.

63. Ahamed, T.R.N.; Rao, K.G.; Murthy, J.S.R. GIS-based fuzzy membership model for crop-land suitability analysis. Agric. Syst. 2000, 63, 75-95. [CrossRef]

64. Aggelopoulou, A.D.; Bochtis, D.; Fountas, S.; Swain, K.C.; Gemtos, T.A.; Nanos, G.D. Yield prediction in apple orchards based on image processing. Precis. Agric. 2010, 12, 448-456. [CrossRef]

65. Swain, K.C.; Thomson, S.J.; Jayasuriya, H.P.W. Adoption of an unmanned helicopter for low-altitude remote sensing to estimate yield and total biomass of a rice crop. Trans. ASABE 2010, 53, 21-27. [CrossRef]

66. Mustafa, A.A.; Singh, M.; Sahoo, R.N.; Ahmed, N.; Khanna, M.; Sarangi, A.; Mishra, A.K. Land Suitability Analysis for Different Crops: A Multi Criteria Decision Making Approach using Remote Sensing and GIS. Researcher 2011, 3, 61-84.

67. Marraccini, E.; Gotor, A.; Scheurer, O.; Leclercq, C. An Innovative Land Suitability Method to Assess the Potential for the Introduction of a New Crop at a Regional Level. Agronomy 2020, 10, 330. [CrossRef]

(C) 2020 by the authors. Licensee MDPI, Basel, Switzerland. This article is an open access article distributed under the terms and conditions of the Creative Commons Attribution (CC BY) license (http://creativecommons.org/licenses/by/4.0/). 